\title{
PELATIHAN KOPING RELIGIUS DALAM MENURUNKAN KECEMASAN PADA PENDERITA KISTA OVARIUM
}

\author{
Nindy Amita ${ }^{1}$, Hepi Wahyuningsih ${ }^{2}$, Indahria Sulistyarini ${ }^{3}$ \\ ${ }^{1}$ Universitas Islam Riau, \\ ${ }^{2,3}$ Universitas Islam Indonesia \\ nindyamita.na@gmail.com,983200104@uii.ac.id,033200101@uii.ac.id
}

\begin{abstract}
The research conducted by researchers aimed to determine how effective religious coping training was in reducing anxiety in patients with ovarian cysts. The hypothesis in this study is that there are differences in anxiety in the treated group. This can be seen from the pre-test, post-test, and follow-up. Thus, the treated group was more able to reduce anxiety in patients with ovarian cysts. The research design carried out by the researcher was a one-group pretest and posttest design. The scale used in the study was the SAI (State Anxiety Disorder) scale. Data analysis used the Wilcoxon test statistical technique. The results of the study proved that religious coping training was able to reduce anxiety in patients with ovarian cysts. The results showed that the pre-test and post-test sig was 0.043 and $p<0.05$. This result explains the difference between the pre-test and post-test scores. The changes in the participants' anxiety had given rise to changes before and after the training was given. The pre-test value with the follow-up value also has the same modifier, namely the sig value obtained is 0.043 and $p<0.05$. There are differences in research subjects' anxiety before being given training and after being given training given distance measurements for 2 weeks. The results of the hypothesis in this study were accepted, namely that there were differences in anxiety in the groups given treatment in this study.
\end{abstract}

Keywords: Religious Coping, Anxiety, Ovarian Cysts

\begin{abstract}
ABSTRAK
Tujuan dari penelitian yang dilakukan oleh peneliti adalah untuk mengetahui seberapa efektif pelatihan koping religius dalam menurunkan kecemasan pada pasien kista ovarium. Hipotesis dalam penelitian ini adalah ada perbedaan kecemasan pada kelompok yang diberi perlakuan. Hal itu dapat dilihat dari pre-test, post-test dan tindak lanjutnya. Dengan demikian, kelompok yang diobati lebih banyak dapat mengurangi kecemasan pada pasien dengan kista ovarium. Desain penelitian yang dilakukan oleh peneliti adalah one group pretest and posttest design. Skala yang digunakan dalam penelitian adalah skala SAI (State Anxiety Disorder). Analisis data menggunakan teknik statistik uji Wilcoxon. Hasil penelitian membuktikan bahwa pelatihan koping religius mampu menurunkan kecemasan pada pasien kista ovarium. Hasil penelitian menunjukkan bahwa pretest dan post-test sig sebesar 0,043 dan $\mathrm{p}<0,05$. Hasil ini menjelaskan adanya perbedaan antara nilai pre-test dan post-test. Perubahan kecemasan peserta sendiri telah memberikan perubahan sebelum pelatihan dan setelah pelatihan diberikan. Nilai pre-test dengan nilai follow up juga memiliki modifikator yang sama yaitu diperoleh nilai sig sebesar 0,043 dan $\mathrm{p}<0,05$. Terdapat perbedaan subjek penelitian kecemasan sebelum diberikan pelatihan dan setelah diberi pelatihan diberikan pengukuran jarak selama 2 minggu. Hasil hipotesis dalam penelitian ini diterima yaitu ada perbedaan kecemasan pada kelompok yang diberikan perlakuan dalam penelitian ini.
\end{abstract}

Kata Kunci: Koping Religius, Kecemasan, Kista Ovarium

\begin{tabular}{|c|c|c|c|}
\hline FIRST RECEIVED: & REVISED: & ACCEPTED: & PUBLISHED: \\
26 March 2020 & 14 April 2021 & 18 April 2021 & 28 April 2021 \\
\hline
\end{tabular}




\section{PENDAHULUAN}

Pada saat ini banyak bermunculan penyakit-penyakit yang dapat menimbulkan kecemasan pada diri individu. Penyakit tersebut dapat menyerang siapa saja baik wanita ataupun pria. Penyakit sering terjadi pada wanita saat ini adalah asma, hipertensi, diabetes melitus serta kanker (KEMENKES, 2012). Penyakit-penyakit tersebut merupakan penyebab angka kematian semakin tinggi di Indonesia (KEMENKES, 2012). Berdasarkan data Riskesdas, prevalensi tumor/kanker di Indonesia menunjukkan adanya peningkatan dari 1.4 per 1000 penduduk di tahun 2013 menjadi 1,79 per 1000 penduduk pada tahun 2018. Prevalensi kanker tertinggi adalah di provinsi DI Yogyakarta 4,86 per 1000 penduduk, diikuti Sumatera Barat 2,47 79 per 1000 penduduk dan Gorontalo 2,44 per 1000 penduduk. (KEMENKES, 2019).

Adanya rutinitas pekerjaan yang padat dan menyita waktu sering kali menjadi alasan oleh banyak wanita untuk sulit menjaga kesehatan. Hal ini ditambah lagi pada saat sekarang banyak wanita yang memiliki gaya hidup yang kurang sehat dan memiliki sedikit waktu untuk olahraga secara teratur. Pada dasarnya banyak penyakit yang terjadi pada wanita sebelum sampai pada tingkatan kanker. Salah satunya adalah penyakit kista rahim atau kista ovarium yang dapat bertahap menjadi kanker rahim atau ovarium jika tidak ditangani secara baik.

Kista ovarium merupakan suatu kantong abnormal yang berisi cairan atau setengah cair yang dapat tumbuh pada indung telur (Taufiqoh, 2012). Taufiqoh juga menjelaskan bahwa berdasarkan survey yang dilakukan oleh Demografi Kesehatan Indonesia menunjukkan angka pertumbuhan penyakit kista ovarium di Indonesia pada tahun 2012 mencapai $37,2 \%$ dan hal ini terjadi pada wanita yang berusia 20-50 tahun. Remaja yang sedang mengalami prapubertas cenderung lebih beresiko dalam mengembangkan kista. Kista ovarium dapat terjadi pada wanita pubertas sekitar 2\%-5\%. Hal ini diketahui ketika menjalani USG dan kista sebagian besar telah berkembang $1 \mathrm{~cm}$ (Zolton \& Maseelall, 2013). Rofe, Auslender \& Dirnfeld (2013) menjelaskan bahwa frekuensi relatif dari kista ovarium memiliki presentare $24 \%$ dari semua jenis kista ovarium. Kista jinak sebenar $70 \%$ dan kista ganas sebenar $6 \%$. Hasil penelitian tersebut dapat mengartikan banyak wanita yang mengidap kista jinak. Kista jinak merupakan kista yang memiliki pertumbuhan sebenar 3 - $8 \mathrm{~cm}$ (Hadibroto, 2005).

Wawancara dilakukan kepada $\mathrm{RH}$ yang berusia 24 tahun. RH mengidap kista ovarium sejak pertengahan tahun 2014. Sebelum meng- 
etahui bahwa subjek mengalami penyakit kista ovarium, RH tidak mengalami menstruasi selama 3 bulan. RH merasakan sakit seperti ditusuk-tusuk pada bagian perut. Hal ini membuat RH sangat takut dan memberanikan diri untuk memeriksakan diri ke dokter. Melalui proses USG yang dilakukan diketahui bahwa RH mengalami kista ovarium dengan pertumbuhan kista sudah $5 \mathrm{~cm}$. Hal ini membuat RH semakin takut dengan apa yang dialami. RH berpikiran bahwa penyakit yang dialami ini membuat RH tidak dapat memiliki keturunan setelah menikah. RH merasa bahwa pertumbuhan kista semakin bertambah jika perut RH sakit dan menstruasi yang tidak lancar pada setiap bulannya. Penyakit kista ovarium ini semakin membuat RH cemas dan harus mengkonsumsi obat secara terus menerus. Obat diperlukan RH untuk mengurangi rasa sakit ketika menstruasi dan mencegah kista semakin membesar.

Penderita penyakit kista lainnya yaitu AF. AF saat ini berusia 22 tahun dan belum menikah. AF menjelaskan bahwa telah mengalami kista ovarium pada saat berusai 21 tahun. Dokter mengatakan pada saat itu AF sudah berada pada stadium 4 dan disarankan untuk melakukan operasi pengangkatan kista. Ketika mengetahui bahwa diri AF mengalami kista, AF menolak dengan keras untuk melakukan operasi dan memilih untuk mengkonsumsi obat herbal. AF menjelaskan bahwa ketika mentsruasi, perut AF sangat sakit dan ini membuat AF semakin takut dengan penyakit yang dialami. AF takut kista bertambah besar dan berpikiran bahwa ketika kista bertambah besar maka AF akan kesulitan dalam beraktivitas sehari-hari. AF mengatakan ketika mentruasi AF sulit beraktivitas dan sering tidak mengikuti perkuliahan.

Wawancara yang telah dilakukan kepada RH dan AF membuktikan bahwa munculnya kecemasan pada penderita kista ovarium meliputi munculnya pemikiran negatif. Pemikiran negatif dari penderita kista ovarium ini menyebabkan adanya ketegangan dan kekhawatiran jika kista akan mengalami pertumbuhan. Kekhawatiran dan kecemasan penderita kista ovarium, mengeluarkan respon seperti tidak bersedia untuk melakukan operasi atau pengangkatan kista. Hal ini membuat diri penderita semakin cemas dan tingkat kekhawatiran yang semakin bertambah.

Kecemasan dan kekhawatiran yang berlebihan dapat berdampak yang signifikan dalam kehidupan (Buchanan, Milroy, Baker, Thompson \& Levack, 2010). Perubahan fisik dapat terlihat dengan jelas apabila seseorang mengalami kecemasan. Tanda kecemasan yang paling jelas terlihat adalah gangguan pencernaan dan kegelisahan (Buchanan, Dkk, 2010). Penderita kista mengalami 
kekhawatiran di dalam diri. Kekhawatiran akan pertumbuhan kista yang terbilang cepat serta ketakutan atas kehamilan yang sulit dipertahannya.

Kecemasan berkaitan erat dengan kesehatan. Cummings \& Pargament (2010) menjelaskan bahwa salah satu faktor mempengaruhi kecemasan individu yang mengalami gangguan kesehatan adalah agama. Agama dinilai dapat memberikan perubahan emosional, perilaku pada individu yang mengalami kecemasan. McCoubrie \& Davies (2006) menambahkan bahwa ketegangan yang dialami individu dapat menurun apabila individu tersebut dapat lebih dekat dengan religiusitas. Tentu saja hal ini akan menggambarkan bahwa penderita kista yang mengalami ketegangan atau ketakutan tersendiri dikarenakan oleh penyakit yang dialaminya akan mengalami penurunan tingkat kecemasan apabila menyerahkan diri kepada Tuhan Yang Maha Esa.

Koping adalah kemampuan seseorang dalam mengatasi masalah atau menangani tuntutan yang menimbulkan tekanan (Atkinson, Smith dan Bem, 2004). Salah satu bentuk koping adalah Koping religius. Koping religius adalah suatu penyelesaian masalah dengan melibatkan agama (Pargement, Koenig \& Perez, 2000). Pargement dkk menjelaskan walaupun koping memiliki nilai yang positif dan disertai oleh agama maka akan tercipta suatu penyelesaian masalah yang baik. Pada hal ini koping religius dapat menurunkan kecemasan penderita kista. Kecemasan yang dialami oleh penderita kista merupakan kecemasan yang banyak mengkhawatirkan dampak psikologis ke masa yang akan datang. Kecemasan tentang kehamilan ataupun pengangkatan kista ovarium yang dilakukan melalui operasi. Tentu saja hal ini membawa kekhawatiran tersendiri bagi penderitanya. Cummings \& Pargament (2010) menjelaskan bahwa fungsi dari koping religius itu sendiri dapat memprediksi hasil dan memahami agama untuk dapat memberikan ketenangan bagi suatu individu.

$$
\text { Larson dalam Subandi }
$$
memaparkan bahwa relevansi klinis dari religiusitas dapat dikategorikan menjadi empat golongan yaitu, (1) Pencegah penyakit, (2) Penyesuaian terhadap penyakit, Kesembuhan dari operasi, (4) Meningkatkan hasil pengobatan. Subandi (2013) juga menjelaskan bahwa agama dapat membantu proses koping dalam menghadapi penyakit. Agama merupakan salah satu faktor protektif dalam kehidupan dan mencegah hal-hal yang diluar kendali manusia. Pendekatan diri kepada Tuhan akan membuat diri individu semakin dapat mengatasi suatu permasalahan yang sedang dihadapi. 
Pargament, Koenig, \& Hahn (2004). lebih lanjut menjelaskan bahwa religiusitas adalah bagian sentral dari konstruksi koping yang digunakan. Seorang individu yang memiliki nilai religius tentu lebih dapat melihat suatu permasalahan melalui pemaknaan yang dilakukan. Berdasarkan uraian serta keterangan yang telah diperoleh diatas membuat peneliti melakukan penelitian mengenai efektifitas pelatihan koping religius dalam menurunkan kecemasan pada penderita kista ovarium. Peneliti mengajukan pertanyaan penelitian apakah pelatihan koping religius dapat menurunkan kecemasan pada penderita kista ovarium. Hipotesis penelitian adalah ada perbedaan kecemasan pada penderita kista ovarium sebelum serta sesudah diberikannya pelatihan koping religius.

\section{METODE PENELITIAN}

Penelitian dilakukan kepada penderita kista ovarium, beragama Islam, belum menikah atau sudah menikah, belum pernah melakukan operasi serta bersedia mengikuti sesi pelatihan. Penelitian dilakukan di rumah sakit X Yogyakarta. Jumlah subjek penelitian pada awalnya adalah 6 orang, namun subjek yang mengikuti semua rangkaian kegiatan berjumlah 5 orang. Penelitian ini menggunakan desain penelitian one group pretest and posttest design (Myers \& Hansen,
2002). Desain penelitian ini digunakan karena adanya keterbatasan subjek penelitian yang jumlah subjek sedikit atau ukuran sampel kecil.

Metode analisis data menggunakan metode kuantitatif serta metode kualitatif. Metode kuantitatif dilakukan untuk menguji hipotesis yang dilakukan dengan menggunakan analisis Non Parametrik Wilcoxon Test. Ini bertujuan untuk mengetahui perbedaan tingkat kecemasan pada penderita kista ovarium akibat adanya perbedaan hasil perlakuan (prates) dan setelah perlakuan (pascates) serta dilakukannya tindak lanjut. Metode kualitatif yang digunakan dalam penelitian ini adalah mengetahui proses pelatihan koping religius pada penderita kista ovarium sebelum diberikan pelatihan dan setelah pelatihan diberikan. Analisis data secara kualitatif dilakukan dengan hasil observasi dan wawancara kepada subjek penelitian.

\section{HASIL DAN PEMBAHASAN}

Penelitian ini bertujuan untuk mengetahui apakah pelatihan koping religius dapat menurunkan kecemasan pada penderita kista ovarium. Hasil yang diperoleh dalam penelitian ini menunjukan bahwa pelatihan koping religius dapat menurunkan kecemasan yang dimiliki oleh penderita kista ovarium. Hal 
ini dapat dilihat dari perubahan kecemasan pada subjek sebelum diberikan perlakuan dan setelah diberikan perlakuan.

Berdasarkan analisis uji hipotesis yang telah dilakukan menunjukan bahwa ada perbedaan kecemasan pada kelompok eksperimen antara sebelum diberikan perlakuan dan setelah diberikan perlakuan. Berdasarkan analisis dengan teknik wilcoxon didapatkan bahwa perolehan prates dan pasca tes adalah 0,043 dan nilai prates dan tindak lanjut juga memperoleh hasil 0,043. Hal ini dapat dikatakan signifikan karena nilai $\mathrm{p}<$ 0,05 .

\section{Tabel Uji Hipotesis}

\begin{tabular}{lcc}
\hline Pengukuran & \multicolumn{2}{l}{ Uji hipotesis } \\
& $\mathbf{Z}$ & Sig \\
& & \\
\hline Prates - Pasca Tes & -2.023 & 0,043 \\
Prates - Tindak Lanjut & -2.023 & 0,043 \\
& & \\
\hline
\end{tabular}

Berdasarkan hasil uji hipotesis yang telah dilakukan pada pengukuran skala prates, pasca tes dan tindak lanjut. Diperoleh hasil bahwa prates dan pasca tes memperoleh nilai sig sebesar 0,043 dan $\mathrm{p}<0,05$. Hal ini dapat menunjukan bahwa ada perbedaan antara nilai prates dan nilai pasca tes. Perubahan kecemasan yang dimiliki oleh peserta memiliki perubahan sebelum diberikan perlakuan dan setelah diberikan perlakuan. Nilai prates dengan nilai tindak lanjut juga memiliki perubah yang sama, yaitu memperoleh nilai sig sebesar 0,043 dan $p<0,05$. Ada perbedaan kecemasan subjek penelitian pada sebelum diberikan perlakuan dan setelah diberikan perlakuan yang memiliki jarak ukur selama 2 minggu. Ini dilakukan sesuai dengan kesediaan klien untuk mengikuti sesi penelitian. Subjek diberikan tugas untuk terus melakukan langkah-langkah peneltian yang telah disampaikan pada saat diberikan perlakuan.

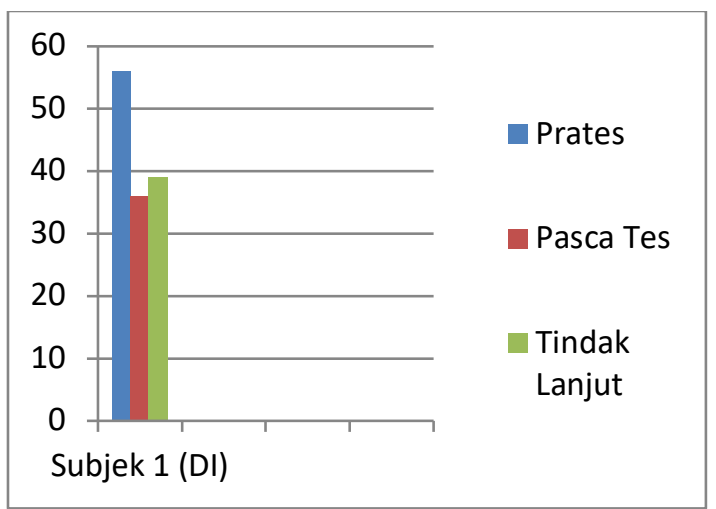

Gambar 1 : Perbandingan Skor Skala Kecemasan Subjek 1

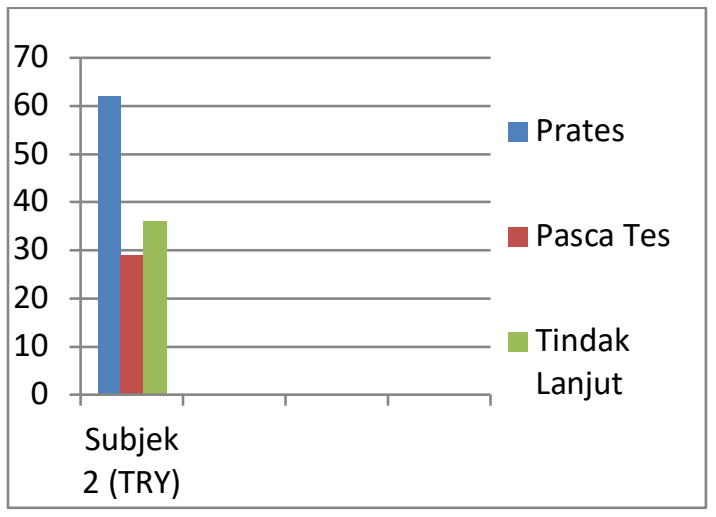

Gambar 2: Perbandingan Skor Skala Kecemasan Subjek 2 


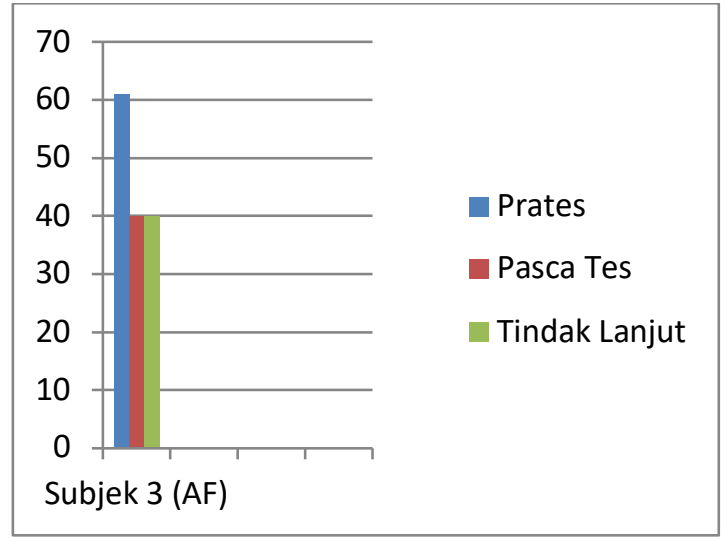

Gambar 3. Perbandingan Skor Skala Kecemasan Subjek 3

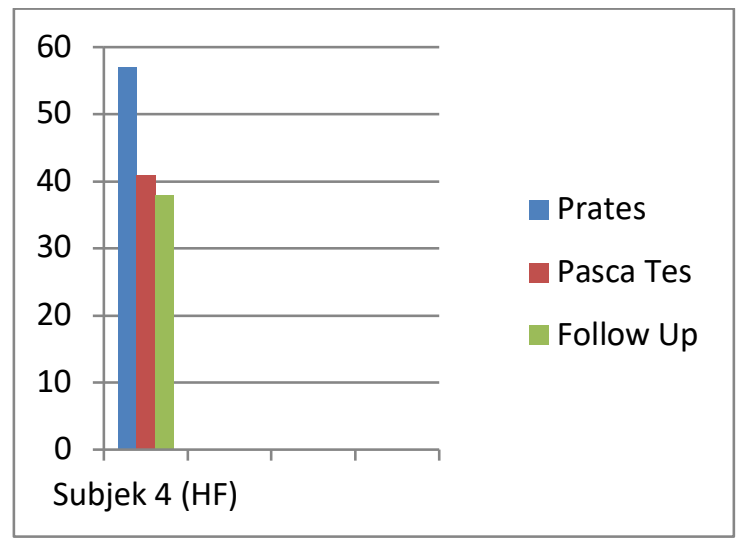

Gambar 4: Grafik Perbandingan Skor Skala Kecemasan Subjek 4

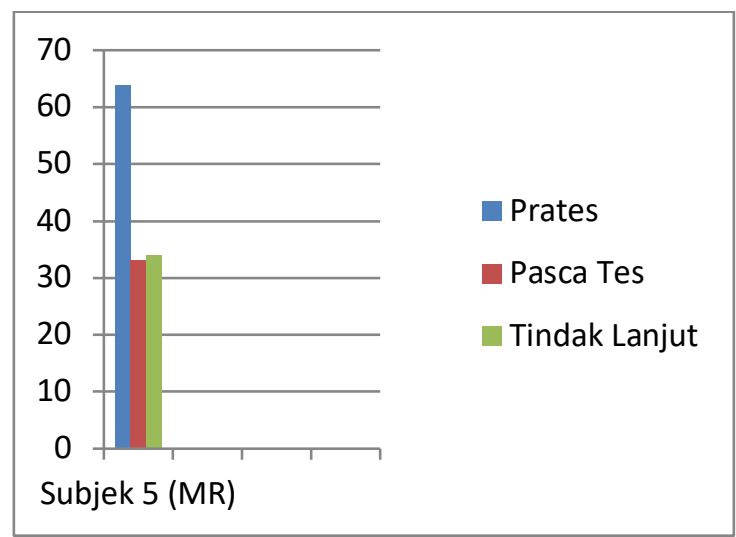

Gambar 5: Grafik Perbandingan Skor Skala Kecemasan Subjek 5

Berdasarkan penjelasan diatas maka dapat ditarik kesimpulan bahwa pelatihan koping religius dapat menurunkan tingkat kecemasan pada penderita kista ovarium. Pelatihan koping religius yang telah dilakukan adalah mengajarkan para penderita kista ovarium untuk mengenali terlebih dahulu pikiran serta perasaan yang dimiliki serta pengendalian diri, pemahaman tentang dzikir dan mensyukuri nikmat yang telah diberikan oleh Allah SWT.

Tahapan awal pelatihan koping religius adalah melatih subjek untuk mengenali terlebih dahulu emosi yang dimiliki dan menemukan makna dari apa yang telah diberikan oleh Allah SWT. Mengenali diri melalui pemikiran serta perasaan dan respon yang dimunculkan. Subjek dilatih untuk menemukan hal potitif di dalam diri subjek sehingga subjek dapat menimbulkan reaksi perilaku yang positif. Selama proses pelatihan, subjek tidak dengan mudah mampu mengendalikan pemikiran ataupun suasana hati. Akan tetapi, subjek dapat mengenali halhal positif dalam diri yang membangkitkan semangat dalam beraktivitas. Pentingnya proses ini dilakukan untuk membantu peserta mengenali sikap yang ditunjukan karena adanya suatu peristiwa yaitu sakit kista ovarium.

Pargement, Koenig, dan Perez, (2000) menjelaskan bahwa suatu proses kognitif baik untuk dilakukan pada individu yang memiliki suatu peristiwa traumatik atau tidak menyenangkan yang akan mempengaruhi cara 
pandangnya terhadap masa depan. Suatu peristiwa yang terjadi dalam diri individu menciptakan suatu pemikiran. Suatu hal yang positif akan menciptakan suatu makna yang positif. Suatu makna yang terbentuk dari suatu pemikiran dan interpretasi yang positif akan menimbulkan suatu harapan serta perasaan yang positif.

Tahapan selanjutnya adalah mengenali dzikir dan berlatih dzikir. Sesi dzikir dilakukan untuk memperoleh pengendalian diri dan mendapatkan ketenangan diri dan mendekatkan diri kepada Allah SWT. AdzDzakiey (2015) menjelaskan bahwa menyebut nama Allah secara berulang (dzikir) mampu untuk menyembuhkan jiwa dan menyembuhkan berbagai penyakit. Pengendalian diri melalui dzikir dilakukan karena ketika situasi menekan terjadi maka akan menunculkan reaksi dan emosi yang seharusnya untuk dikontrol. Dzikir membantu individu untuk membentuk persepsi yaitu keyakinan bahwa tekanan atau masalah yang dimiliki dapat dihadapi dengan dengan baik dengan bantuan Allah SWT.

Kecemasan yang muncul akibat dari suatu permasalahan tentunya akan berakibat dalam aktivitas sehari-hari. Kecemasan dapat muncul dari pikiran yang berlebihan terhadap suatu peristiwa yang belum terjadi ataupun telah terjadi. Pada saat seorang individu dapat menemukan makna dari suatu peristiwa yang menimpa dirinya maka akan tercipta pemaknaan terhadap kebesaran Allah SWT. Hal ini diperkuat oleh Cummings \& Pargament (2010) bahwa seseorang yang dapat menemukan tentang pemaknaan kepada Tuhan dapat lebih berpikir secara logis dan menerima tentang apa yang telah ditetapkan oleh Tuhan. Seseorang ketika memaknai apa yang telah ditetapkan kepada dirinya maka akan tercipta suatu kenyamaan di dalam diri.

Setelah menemukan makna dari kebesaran Allah SWT. Johansson, Dkk (2013) dalam penelitiannya menemukan bahwa doa, menghindari perbuatan yang negatif serta mempertahankan perbuatan yang positif. Doa merupakan hal yang sangat dianjurkan. Doa akan mendekatkan diri individu dengan Tuhan Yang Maha Kuasa. Banyak cara yang dapat dilakukan ketika meminta kepada Allah SWT. Dzikir merupakan salah satu media yang dapat mendekatkan diri kepada Allah SWT (AdzDzakiey, 2015).

Lowis, Edwards \& Buton (2009) bahwa individu yang menyerahkan diri kepada tuhan melalui doa akan dapat membuat diri merasa nyaman dan menurunkan kadar rasa cemas yang dialami. Dzikir dan doa menempati posisi paling vital dalam proses menghambakan diri kepada sang khaliq. Dimana tujuan utama Allah SWT menciptakan manusia adalah untuk 
beribadah dan mengabdi kepada-Nya. Salah satu ibadah dapat dilakukan dengan doa dan berdzikir (Mahfani, 2006). Individu yang merasakan suatu perubahan fisik, emosi dan perilaku di dalam dirinya membutuhkan sebuah kenyamanan sehingga metode dzikir dapat berguna bagi penderita kista ovarium yang mengalami kecemasan.

Tahapan selanjutnya adalah berlatih untuk kebersyukuran. Pada tahap ini, peserta diajarkan untuk mengenali hal apa saja yang telah diperoleh dapat kehidupan dan seberapa besar hal tersebut dapat disyukuri oleh subjek penelitian. Masykur (2013) menjelaskan bahwa syukur adalah keputusan yang akan dilatih setiap harinya. Syukur dimulai dari halhal kecil dalam kehidupan kemudian ditingkatkan kepada rasa syukur terhadap setiap pemberian dari Allah SWT. Setiap individu yang meningkatkan kualitas dari rasa syukur yang dimiliki maka akan membuat individu lebih meningkatkan keimanan.

Wurm, Edlund, Tillfors and Boersma (2016) menjelaskan dalam penelitiannya bahwa kecemasan muncul karena terdapat kerentanan emosi dalam diri individu yang sulit untuk dikendalikan. Pada penelitian ini, Peneliti memberikan strategi koping berbentuk religiusitas kepada subjek penelitian sehingga ketika subjek penelitian memiliki strategi koping yang baik dalam menyikapi sakit yang diderita maka rasa tegang dan emosi yang ada dalam diri individu dapat berkurang. Penelitian yang dilakukan peneliti membuktikan bahwa pasien dengan kista ovarium yang telah diberikan pelatihan berupa koping religius maka dapat menurunkan kecemasan yang dimilikinya.

Keberhasilan pelatihan koping religius didukung oleh antusias dari subjek penelitian serta dan penerimaan diri yang baik dari subjek karena belum pernah mengikuti pelatihan seperti yang dilakukan oleh peneliti.

Evaluasi secara keseluruhan membuktikan bahwa pelatihan koping religius dapat membuat subjek merasakan kenyamanan dalam diri, tidak menghadapi masalah sendiri namun juga ada orang lain yang juga memiliki masalah yang sama serta adanya ilmu untuk dapat diaplikasikan setelah selesainya pelatihan yang diberikan. Subjek mendapatkan wawasan dan ilmu untuk dapat dipraktikan dalam kehidupan sehari-hari.

Pelatihan koping religius yang dipandu oleh seorang psikolog atau fasilitator yang berpengalaman. Materi yang disampaikan dapat dipahami oleh subjek penelitian. Fasilitator juga berperan dalam memberikan contoh dalam setiap sesinya. Desain penelitian dalam penelitian ini mengacu pada aktivitas pembelajaran melalui pengalaman yaitu, belajar melalui pengalaman, proses 
pembelajaran akan menjadi efektif karena individu mendapatkan stimulus dari fasilitator (Afiantin, 2004). Materi disampaikan dengan menggunakan power point dari laptop ke LCD sehingga peserta mampu memperhatikan penjelasan dari fasilitator dengan baik. Subjek penelitian juga mendapatkan modul dan materi pelatihan sehingga subjek lebih dapat memahami isi dari pelatihan koping religius.

Ursaru, Crumpei And Crumpei (2014) menjelaskan dalam penelitian yang telah dilakukan yaitu mengetahui koping religius pada penderita kanker payudara menjelaskan bahwa kualitas hidup yang ditampilkan oleh penderita penyakit kronik akan meningkat seiring dilakukannya pendekatan kepada Tuhan Yang Maha Esa. Penderita penyakit kronik akan merasa sehat secara psikis sehingga rasa tegang yang dialami dapat berkurang. Penelitian ini mendukung penelitian yang telah dilakukan oleh peneliti, yaitu pelatihan koping religius dalam menurunkan kecemasan pada penderita kista ovarium. Subjek penelitian mengalami penurunan kecemasan yang dapat terlihat dari data kuantitatif maupun kualitatif yang dilakukan peneliti kepada subjek penelitian. Subjek mengalami penurunan kecemasan dikarenakan ada niat dan usaha untuk lebih mendekatkan diri kepada sang pencipta dan mensyukuri pemberian yang telah diberikan oleh Allah SWT.

\section{SIMPULAN}

Berdasarkan hasil analisis data kuantitatif dan kualitatif diperoleh bahwa penderita kista ovarium yang mendapatkan pelatihan koping religius dalam menurunkan tingkat kecemasan yang dimiliki. Maka dapat disimpulkan bahwa pelatihan koping religius mampu efektif dalam menurunkan kecemasan pada penderita kista ovarium.

Subjek pelitian melakukan aplikasi praktik koping religius yang telah diberikan selama pelatihan. Peneliti selanjutnya dapat melakukan monitoring terhadap praktik koping religius dan dapat meneliti dan memberikan pelatihan koping religius pada subjek yang mengalami sakit fisik lainnya.

\section{DAFTAR PUSTAKA}

Atkinson, Rita.L., Atkinson, Richard C., Smith., Edward E. \& Bem, Daryl J. (2004). Pengantar psikologi. edisi ke-11, jilid 2. Batam: Interaksara.

Adz-Dzakiey, H. B. (2015). Prophetic intelligence kecerdasan kenabian. Bantul; Al-Manar.

Buchanan, D., Milroy, R., Baker, L., Thompson, A. M \& Levack, P. A. (2010). Perceptions of anxiety in lung cancer patients and their support network. Support Care Cancer. (18). 29- 36. 
Cummings, J. P., \& Pargament, K. I. (2010). Medicine for the spirit: religious coping in individuals with medical conditions. Journal of Religions, (1), 28-53

Hadibroto, B. R. (2005). Laparoskopi pada kista ovarium. Majalah Kedokteran Nusantara. 38(3). $260-263$.

Johansson, F. G., Wolfe, M. E., Reddick, B., Goldstein, N., \& Lawal, T. (2013). The relationships among coping strategies, religious coping, and spirituality in African American women with breast cancer receiving chemotherapy. Oncology Nursing. 40(2). 120- 132.

KEMENKES RI. (2012). Buletin jendela data dan info kesehatan. Jakarta: Jendela Data.

KEMENKES RI. (2019). Hari kamker sedunia. Jakarta: Biro Komunikasi dan Pelayanan Masyarakat

Lowis, M. J., Edwards, A. C \& Burton, M. (2009). Coping with retirement: well-being, health, and religion. Journal of Psychology. 143(4). 427-448

Mahfani, K. (2006). Keutamaan doa dan dzikir untuk hidup bahagia sejahtera. Jakarta; PT Wahyu Mulia.

Masykur, M.S. (2013). Terapi Bersyukur Menjadi Kaya Harta, Bahagia Ala Nabi Muhammad SAW. Yogyakarta; Massamedia.

McCoubrie, C. R. \& Davies, N. A. (2006). Is there a correlation between spirituality and anxiety and depression in patients with advanced cancer? Support Care Cancer. (14). 379-385.

Myers, A., \& Hansen, C.H. (2002). Experiment psychology. The USA. Wadsworth.

Pargement, K. I., Koenig, H, G \& Perez, L. M. (2000). The many methods of religious coping: development and initial validation of the RCOPE. Journal of Clinical Psychology. 56(4). 519-543

Pargament, K.I., Koenig, H. G., Tarakeshwar, N.A., Hahn, J. (2004). Religious coping methods as predictors of psychological, physical and spiritual outcomes among medically Ill elderly patients: a two-year longitudinal study. Journal of Health Psychology. 9(6). 713-730.

Rofe, G., Auslender, R \& Dirnfeld, M. (2013). Benign ovarian cysts in reproductive-age women undergoing assisted reproductive technology treatment. Journal of Obstetrics and Gynecology. (3), $17-22$.

Subandi, M. A. (2013). Psikologi agama \& kesehatan mental. Yogyakarta; Pustaka Belajar.

Taufiqoh, S. (2012). Hubungan antara umur ibu dengan tingkat keganasan kista ovarium di rumah sakit muhammadiyah Surabaya. Jurnal Ilmu Kesehatan, 5(2). 52-56.

Ursaru, M., Crumpei, I \& Crumpei, G. (2014). Quality of life and religious coping in women with breast cancer. Journal of cocial and Behavioral Sciences (114). 322326.

Wurm, M., Edlund, S., Tillfors, M., Boersma, K. (2016). Characteristics and consequences of the co-occurrence between social anxiety and pain-related fear in chronic pain patients receiving multimodal pain rehabilitation treatment. Journal of Scandinavian of Pain. (12) 45-52.

Zolton, J. R., Maseelall. (2013). Evaluation of ovarian cysts in adolescents. Journal of Obstetrics and Gynecology. (3), 12-16. 